\title{
Televisi Pembangunan Pedesaan
}

\author{
Oos M. Anwas \\ Pustekkom Kemdiknas, e-mail: anwasipb@yahoo.co.id,
}

\begin{abstract}
Abstrak: Tulisan ini merupakan kajian dalam menindaklanjuti saran dari hasil penelitian penulis (2009), tentang perlunya mewujudkan Televisi Pembangunan Pedesaan guna memenuhi kebutuhan informasi yang terus berkembang bagi peningkatan kualitas SDM masyarakat pedesaan. Melalui hasil kajian literatur dan bahasan diketahui bahwa media televisi merupakan media massa yang paling digemari masyarakat dan setiap tahun cenderung meningkat. Media yang menyajikan pesan audio visual ini juga mampu mempengaruhi perilaku dan kehidupan masyarakat. Untuk merealisasikan Siaran Televisi Pembangunan Perdesaan tidak perlu membangun setasiun televisi baru, akan tetapi mengoptimalkan TVRI sebagai setasiun televisi publik, baik menggunakan teknologi analog apalagi teknologi digital yang bisa mengatasi keterbatasan frekuensi. Siaran ini mengudara secara nasional selama 24 jam, melalui satu channel khusus dengan pola siaran 8 jam per hari, yang kemudian diulang pada sore dan malam harinya, sehingga masyarakat desa dapat mengikuti sesuai kesempatan yang dimilikinya. Substansi acara dikembangkan mengacu pada prinsip-prinsip pembangunan masyarakat pedesaan yang sesuai dengan kebutuhan dan potensi masyarakat desa.
\end{abstract}

Kata kunci: televisi pembangunan pedesaan, komunikasi pembangunan, dan masyarakat pedesaan

\begin{abstract}
This paper is a study in the follow advice from the research writer (2009), about the need to realize the Television Rural Development in order to meet the growing information needs for improving the quality of rural communities. Through literature review and discussion of results is known that the medium of television is the most popular mass media and society tend to increase every year. Media that presents a visual audio message is also able to influence the behavior and community life. Realizing Rural Development TV broadcasts does not always mean to build a new television station, but it can be made happen by optimizing the public television station TVRI especially with its digital technology that could overcome the frequency limitations. This broadcast aired nationally for 24 hours, via a special channel with an eight-hour-a-day broadcast pattern, which is then repeated in the afternoon and evening, so the villagers can follow the show within their appropriate opportunity.
\end{abstract}

Key words: television rural development, development communication, and rural communities

\section{Pendahuluan}

Anwas (2009) dalam penyusunan disertasi Program Doktor di Pascasarjana Institut Pertanian Bogor (IPB) melakukan penelitian terhadap pemanfaatan media dalam pengembangan kompetensi penyuluh pertanian di Jawa Barat. Salah satu rekomendasi praktis dari hasil penelitian tersebut adalah di Indonesia perlunya merealisasikan Siaran Televisi Pembangunan Pedesaan. Melalui Siaran Televisi Pembangunan Pedesaan, berbagai informasi yang terkait dengan pembangunan pedesaan, misalnya: produksi pertanian, pemasaran hasil-hasil pertanian, kewirausahaan, manajemen, kesehatan keluarga, dan informasi lainnya yang sesuai dengan tuntutan perkembangan zaman dapat dikemas dengan sajian yang menarik dan bermanfaat bagi kemajuan masyarakat desa.

Realitas di era kemajuan teknologi informasi dan komunikasi, banyak pilihan media khususnya media massa yang dapat dimanfaatkan baik sebagai sumber informasi, hiburan, dan juga pendidikan. Banyaknya alternatif media massa, ternyata media televisi merupakan media massa yang sangat populer di semua lapisan masyarakat. Popularitas televisi tidak hanya di perkotaan, melainkan juga karena di pedesaan televisi sangat digemari oleh masyarakat. Hasil kajian Anwas (2009) menunjukkan bahwa substansi acara-acara televisi yang berhubungan langsung dengan 
pertanian atau pembangunan masyarakat pedesaan masih sangat kurang.

Substansi acara televisi lebih dominan oleh unsur hiburan dan aspek lainnya yang kurang memiliki dampak positif bagi peningkatan kualitas hidup dan kesejahteraan masyarakat khususnya di pedesaan. Bahkan dalam beberapa kajian, media masa khususnya televisi seringkali dituduh sebagai salah satu penyebab berkembangnya perilaku negatif di masyarakat, seperti kekerasan, kejahatan, sikap hidup konsumtif, dan perilaku negatif lainnya. Padahal media televisi sangat digemari dan memiliki potensi besar untuk dimanfatkan dalam pendidikan masyarakat.

Tulisan ini merupakan tindak lanjut saran dari hasil penelitian Anwas (2009) tentang perlunya merealisasikan Siaran Televisi Pembangunan Pedesaan, sebagai media massa yang paling digemari dan paling banyak dimiliki masyarakat. Melalui pengembangan Siaran Televisi Pembangunan Pedesaan diharapkan mampu memberikan nilai tambah dalam meningatkan kualitas kehidupan dan kesejahteraan masyarakat terutama di pedesaan. Kajian tulisan meliputi: potensi televisi sebagai media komunikasi pembangunan, kebutuhan informasi melalui media televisi, subtansi Siaran Televisi Pembangunan Pedesaan, sistem penyiaran Televisi Pembangunan Pedesaan, dan strategi pemanfaatan Televisi Pembangunan Pedesaan.

\section{Kajian Literatur dan Pembahasan Televisi sebagai Media Komunikasi Pembangunan}

Televisi sebagai media massa memiliki peran penting dalam komunikasi pembangunan. Hasil studi Schramm (Nasution, 2007) mengemukakan bahwa media massa dapat berperan dalam beberapa hal, yang paling pokok adalah dapat membantu menyebarluaskan informasi tentang pembangunan, dapat mengajar melek huruf serta keterampilan lainnya yang memang dibutuhkan untuk pembangunan masyarakat dan dapat menjadi penyalur suara masyarakat agar turut ambil bagian dalam pembuatan keputusan di negaranya. Menurut Straubhar dan LaRose (2002) media memiliki fungsi sosial sebagai pemelihara kestabilan sosial dengan memberikan peluang kepada masyarakat untuk menemukan kebutuhannya.

Media massa terutama televisi berperan penting sebagai alat perubahan sosial dan perkembangan masyarakat. Peranan media massa yang paling cocok dalam pembangunan adalah sebagai agen perubahan (agent of change), terutama dalam membantu mempercepat proses peralihan masyarakat tradisional ke masyarakat modern (Oepen, 1988).

Di Indonesia media massa telah terbukti memiliki peran penting dalam perubahan sosial dalam masyarakat. Misalnya, keberhasilan Program Keluarga Berencana tidak terlepas dari peran exposure media ini. Dalam bidang pertanian pembangunan jangka panjang melalui program Bimbingan Masal (Bimas) yang ditunjang dengan gencarnya tayangan media khususnya televisi telah mampu meningkatkan kemampuan dan produksi pertanian hingga mencapai swasembada beras. Ini berarti supaya masyarakat mau berpartisipasi dalam pembangunan perlu diinformasikan sebaik-baiknya sehingga masyarakat dapat memahami makna dan manfaat pembangunan untuk dirinya, keluarga atau masyarakat luas. Media massa khususnya televisi memiliki potensi besar untuk menyampaikan informasi dan mempengaruhi masyarakat secara berkelanjutan.

Hasil penelitian dan kajian Wilkinson (1980), Littlejohn (1996), (Severin dan Tankard, 2001), serta McQual dan Windahl (1996) mengenai dampak media menunjukkan bahwa media televisi merupakan kekuatan yang besar bagi kepentingan-kepentingan yang dominan dalam masyarakat. Hal ini karena media televisi dapat menyajikan pesan audio visual, live, dan unsur gerak. Televisi dapat menghadirkan objek-objek yang berbahaya, jauh, kecil, dan objek besar secara nyata. Media televisi juga bisa memanipulasi pesan sesuai dengan yang diinginkan melalui teknik pengambilan gambar, penggunaan grafis/animasi, teknik editing, serta trik-trik lainnya yang menimbulkan kesan tertentu. Di sisi lain, televisi dapat ditonton dalam suasana santai di rumah sambil bercengkerama dengan keluarga, di tempat-tempat umum, bahkan di dalam kendaraan. Semua ini menjadi potensi besar media televisi dimanfaatkan sebagai media komunikasi pembangunan. 
Untuk meningkatkan partisipasi dalam pembangunan diperlukan wawasan yang luas tentang pembangunan tersebut. Dengan kemasan isi pesan yang dibutuhkan, media televisi dapat memberikan dan menambah wawasan terhadap masyarakat terutama melalui indra penglihatan. Media televisi dapat juga menyalurkan aspirasi masyarakat kepada para pengambil kebijakan. Kebutuhan, permasalahan, harapan, atau keluhan masyarakat dapat disalurkan melalui media massa. Acara dialog interaktif dan bentuk acara lainnya merupakan wahana untuk menyalurkan aspirasi masyarakat dalam mempengaruhi para pengambil kebijakan dan masyarakat lainnya terhadap pembanguan yang sedang berlangsung.

Siaran pertanian atau pembangunan pedesaan sesungguhnya sudah lama dilakukan baik oleh TVRI sebagai televisi milik pemerintah dan juga setasiun televisi swasta. Di TVRI misalnya, sejak zaman orde baru pemanfaatan media televisi untuk pertanian sudah dilakukan, misalnya acara "Dari Desa ke Desa" atau acara sejenisnya. Kemudian acara serial sinetron "Desa Idaman dan Saung Tani " TVRI (2006-2007), Kuis Asah Trampil, dialog Menteri Pertanian, variaty show, dan lain-lain. Mulai tahun 2009, di TVRI juga dikembangkan acara serupa yang diberi tajuk "Pelangi Desa", "Daerah Membangun" dan acara lainnya. Begitu pula di beberapa televisi swasta dapat disaksikan acara-acara yang memiliki nuansa pembangunan masyarakat pedesaan. Namun, penyiaran acara tersebut masih terkesan parsial sehingga kurang bisa memenuhi kebutuhan informasi dan meningkatkan kualitas kehidupan masyarakat pedesaan.

Pemanfaatan siaran televisi yang mengkhususkan untuk pemberdayaan petani Pedesaan telah dilakukan oleh pemerintah China. Siaran ini dilakukan melalui satu channel khusus setasiun televisi milik pemerintah yaitu Center of China Television. Pengembangan substansi acara dilakukan oleh kementerian yang membidangi pemberdayaan petani. Siarannya berlangsung 24 jam, serta direlay oleh beberapa televisi lokal. Materi siaran yang sifatnya pembelajaran keterampilan tertentu dibuat dalam format VCD untuk disebarluaskan dan dimanfaatkan oleh kelompok-kelompok tani di pedesaan. Materi siaran dimulai dari produksi pertanian, pemasaran, manajemen, serta informasi lainnya yang terkait dengan agribisnis. Dengan cara ini para petani di berbagai pelosok negeri China tidak hanya menonton hiburan, melainkan juga dapat terus belajar, memperoleh berbagai informasi yang terkait dengan peningkatan kualitas kehidupannya (Pustekkom, 2006).

Pengalaman negeri Tirai Bambu tersebut dapat menguatkan optimisme pengembangan siaran televisi pembangunan pedesaan di Indonesia. Hal ini didasarkan negeri China dan Indonesia memiliki beberapa kesamaan, di antaranya wilayah yang luas dan banyak daerahdaerah pertanian yang sulit dijangkau transportasi darat. Di sisi lain, media televisi sudah popular dan digemari sebagian besar masyarakat termasuk penyuluh dan petani. Oleh karena, itu, pengembangan siaran televisi untuk pertanian optimis dapat dilakukan dalam meningkatkan kualitas SDM petani dan masyarakat pedesaan yang tersebar di berbagai pelosok tanah air.

\section{Kebutuhan Informasi melalui Televisi}

Realitas penduduk Indonesia sebagian besar berada di pedesaan. Menurut Slamet (2003) sekitar 80 persen masyarakat Indonesia hidup di Pedesaan dan hingga sekarang masih banyak rakyat yang belum cukup tersentuh oleh kesempatan berpartisipasi dalam pembangunan, termasuk menikmati hasil pembangunan. Artinya, penduduk Indonesia yang sebagian besar berada di pedesaan tersebut masih tergolong miskin.

Indonesia dikenal sebagai negara agraris. Mata pencaharian penduduknya yang sebagian besar tinggal di pedesaan tersebut adalah bertani. Kehidupan masyarakat bergantung pada bercocok tanam dan hasil pertanian lainnya. Oleh karena itu, upaya mensejahterakan masyarakat Indonesia melalui sektor pertanian menjadi prioritas.

Dalam perspektif pendidikan, upaya mensejahterakan masyarakat Indonesia adalah bagaimana membangun Sumber Daya Manusia yang langsung terkait dengan pertanian. Kualitas para petani, termasuk para penyuluh pertanian yang tersebar di berbagai pelosok pedesaan sangat perlu ditingkatkan. Mereka butuh informasi secara kontinyu yang bermanfaat dalam 
meningkatkan kualitas kehidupannya. Namun, kenyataanya kebutuhan informasi tersebut sulit diperoleh oleh petani di pedesaan. Menurut Hafsah (2009), realitas di Indonesia terjadi kurangnya rasa keadilan terhadap informasi yang diperoleh petani di pedesaan, informasi media massa khususnya televisi yang paling digemari masyarakat didominasi oleh hiburan, sedangkan informasi yang berkaitan dengan pertanian dan pembangunan pedesaan sangat kurang.

Kebutuhan informasi petani khususnya yang terkait dengan informasi usaha pertanian masih kurang, akibatnya SDM petani kita secara umum masih belum bisa bersaing sekalipun dengan negara tetangga. Hal ini terbukti dengan semakin membanjirnya produk pertanian impor di pasar. Menurut Karz (Suryantini, 2003) kebutuhan informasi termasuk dalam kelompok kebutuhan kognetif (cognitive need), yakni kebutuhan yang didasari oleh dorongan untuk memahami dan menguasai lingkungan, memuaskan keingintahuan (curiosity) serta penjelajahan (exploratory). Kebutuhan informasi bagi petani di pedesaan berarti kebutuhan untuk memahami lingkungan sekitar kehidupan mereka, yaitu usaha pertanian dalam meningkatkan kualitas kehidupannya ke arah yang lebih baik, sehingga kesejahteraan mereka bisa meningkat. Oleh karena itu, media televisi sangat berpotensi menjadi media dalam memenuhi kebutuhan informasi di pedesaan.

Menurut data Badan Pusat Statistik (2010), persentase penduduk Indonesia yang berumur 10 tahun ke atas yang menonton televisi di dalam sepuluh tahun terakhir ini menunjukkan peningkatan yang signifikan, yaitu tahun 2003 sebanyak 84,94 persen, tahun 2006 sebanyak 85,86 persen, dan tahun 2009 meningkat menjadi 90,27 persen (Tabel 1 ). Artinya penduduk Indonesia yang tidak menonton televisi di tahun 2009 hanya kurang dari 10 persen. Sebaliknya persentase penduduk Indonesia yang berumur 10 tahun ke atas yang mendengarkan radio cenderung menurun, yaitu tahun 2003 sebanyak 50,29 persen, tahun 2006 sebanyak 40,26 persen, dan tahun 2009 menurun drastis menjadi 23,50 persen. Begitu pula persentase penduduk Indonesia yang berumur 10 tahun ke atas yang membaca koran/majalah cenderung menurun, tahun 2003 sebanyak 23,70 persen, tahun 2006 sebanyak 23,46 persen, dan tahun 2009 sebanyak 18,94 persen. Data ini menguatkan begitu ampuhnya (powerfull) media televisi untuk menyampaikan pesan, mempengaruhi penonton dalam hal ini petani di pedesaan dalam meningkatkan kualitas kehidupannya ke arah yang lebih baik.

Tabel 1. Persentase Penduduk Berumur 10 tahun ke Atas

\begin{tabular}{|l|c|c|c|}
\hline \multicolumn{1}{|c|}{ Indikator } & 2003 & 2006 & 2009 \\
\hline Menonton Televisi & 84.94 & 85.86 & 90.27 \\
\hline $\begin{array}{l}\text { Mendengarkan } \\
\text { Radio }\end{array}$ & 50.29 & 40.26 & 23.50 \\
\hline $\begin{array}{l}\text { Membaca } \\
\text { Koran/Majalah }\end{array}$ & 23.70 & 23.46 & 18.94 \\
\hline
\end{tabular}

Sumber: BPS: 2010

Seiring dengan perkembangan setasiun televisi swasta dan perkembangan teknologi pertelevisian, data di atas menunjukkan begitu digemarinya media televisi dibandingkan dengan media massa lainnya seperti radio dan koran/ majalah. Media televisi dapat menyajikan informasi dalam bentuk audio visual dan juga unsur gerak, serta dapat menyajikan pesan dalam bentuk live. Media televisi juga merupakan media dramatisasi pesan. Pesan-pesan dapat dikemas secara menarik termasuk menyentuh aspek emosional penonton. Dalam pemanfaatannya, televisi dapat ditonton dengan mudah dan duduk santai di rumah atau dimana pun sesuka hati. Lain halnya dengan surat kabar atau majalah perlu kemampuan membaca, atau media radio yang hanya mengandalkan indra pendengaran. Hal ini yang menjadikan media televisi merupakan media yang paling digemari di seluruh dunia termasuk di pedesaan wilayah Indonesia.

Kebutuhan informasi tersebut dapat dipenuhi melalui media dalam hal ini televisi. Menurut McQuail (1995), motif penggunaan media meliputi mencari informasi dan saran, mempelajari masyarakat dan dunia, memperoleh pemahaman tentang kehidupan seseorang, mempunyai dasar untuk hubungan sosial, merasa terhubung 
dengan yang lain, memperoleh jalan ke dunia fiktif, mengisi waktu dan melepaskan ketegangan. Untuk memenuhi kebutuhan informasi tersebut, menggunakan media televisi sangatlah tepat, karena media ini terbukti paling digemari oleh masyarakat kita termasuk di pedesaan (Tabel 1).

\section{Substansi Siaran Televisi Pembangunan Pedesaan}

Substansi siaran televisi pembangunan pedesaan dapat dicermati dari konsep pembangunan. Menurut Bryant dan White (dalam Sumaryo dan Safari, 2007), pembangunan merupakan upaya untuk meningkatkan kemampuan manusia untuk mempengaruhi masa depannya. Implikasi dari konsep Bryant dan White tersebut bahwa pembangunan berarti membangkitkan kemampuan optimal manusia (capacity), mendorong tumbuhnya kebersamaan dan pemerataan nilai kesejahteraan (equity), menaruh kepercayaan dan kesempatan kepada masyarakat untuk membangun (empowerment), membangkitkan kemampuan untuk mandiri (sustainability), dan mengurangi ketergantungan dan menciptakan hubungan yang saling menguntungkan (interdependency). Pembangunan pedesaan berarti meningkatkan kemampuan masyarakat pedesaan melalui pemberdayaan yang sesuai dengan potensi dan kebutuhan mereka menuju pencapaian kemandirian dan kesejahteraan.

Secara lebih rinci Sanders (1958) menjelaskan sepuluh prinsip pembanguan masyarakat khususnya masyarakat pedesaan, yaitu kegiatan harus dikaitkan dengan kebutuhan-kebutuhan dasar masyarakat, kegiatan yang dilakukan memiliki beragam tujuan masyarakat, fokus pada perubahan perilaku masyarakat, meningkatkan partisipasi/pemberdayaan, mendorong pengembangan pimpinan lokal, pemberdayaan wanita dan pemuda, membantu dirinya sendiri, dilakukan secara konsisten, melibatkan organisasi swadaya masyarakat, serta pembangunan tingkat lokal harus paralel dengan skala nasional.

Substansi acara televisi pembangunan pedesaan harus memperhatikan prinsip-prinsip pembangunan masyarakat tersebut. Pembangunan pedesaan tidak terbatas hanya peningkatan usaha pertanian, tetapi banyak aspek kehidupan masyarakat yang perlu ditingkatkan sesuai dengan kebutuhan dan potensi mereka. Masyarakat desa khususnya petani sangat butuh peningkatan kemampuan usaha pertanian mulai dari pengolahan lahan, pemuliaan tanaman, pemupukan, pemeliharaan, hingga panen dan pascapanen. Di sisi lain petani juga sangat perlu kemampuan dalam pemasaran hasil, manajemen pertanian, kewirausahaan, net working, dan kemampuan lainnya sesuai dengan tuntutan perkembangan zaman. Oleh karena itu, sangat perlu dilakukan kajian lebih mendalam melalui analisisi kebutuhan masyarakat. Untuk mendapatkan data yang akurat, analisis kebutuhan dapat menggunakan beberapa teknik. Di sini perlu melakukan trangulasi dengan cara menggunakan beberapa macam teknik seperti nominal group technique, transect, indepth interview, serta menggali data dari berbagai sumber dalam masyarakat.

Melalui suatu kajian hasil analisis kebutuhan, akan diperoleh informasi yang akurat untuk pengembangan acara televisi pembangunan pedesaan. Dengan demikian, acara ini benarbenar sesuai dengan kebutuhan dan potensi masyarakat pedesaan, sehingga diharapkan dapat meningkatkan kualitas kehidupan mereka.

Pengembangan substansi acara Siaran Televisi Pembangunan Pedesaan berada di bawah koordinasi Kementerian Pertanian. Pembiayaan sepenuhnya berasal dari APBN atau APBD dan pihak-pihak lain yang sifatnya tidak mengikat. Dengan demikian, acara Siaran Televisi Pembangunan Pedesaan memiliki idealisme yang kuat. Tujuannya, bukan untuk bisnis mencari keuntungan, tetapi hanya untuk pendidikan, meningkatkan kualitas SDM masyarakat Pedesaan.

Dalam pengembangan materi acara, Kementerian Pertanian bekerja sama dengan berbagai pihak yang terkait dengan pembangunan Pedesaan, antara lain Kementerian Pendidikan Nasional, Kementerian Komunikasi dan Informasi, Kementerian Perikanan dan Kelautan, Kementerian Koperasi UKM, Kementerian Kesehatan, Kementerian Kehutanan, Lembaga Ilmu Pengetahuan Indonesia, lembaga penelitian, organisasi profesi penyuluhan, perguruan tinggi, swasta, serta yang lebih penting lagi adalah melibatkan masyarakat pedesaan. 
Sebagai layaknya acara televisi, di samping materinya harus bermanfaat bagi masyarakat pedesaan, juga unsur kemenarikan acara menjadi penting. Banyak kalangan yang mengibaratkan pesan pendidikan dalam media televisi seperti Jamu, walaupun rasanya pahit tetapi bermanfaat. Artinya, walaupun acara televisi pembangunan kurang menarik, tetapi memiliki manfaat bagi yang menontonnya. Kondisi ini sering terjadi dalam siaran televisi yang memiliki nuansa pendidikan. Akibatnya siaran televisi tersebut kurang diminati karena kalah bersaing dengan televisi lain yang acaranya lebih menarik. Oleh karena itu, sekarang sudah banyak jamu yang dikemas dengan rasa manis, sehingga lebih digemari masyarakat. Acara televisi yang memiliki pesan pembangunan pedesaan tersebut harus dikemas menarik, sehingga enak untuk ditonton. Oleh karena itu, pengembangan materi acara, perlu melibatkan banyak pihak terkait, seperti ahli media, ahli materi, ahli bahasa, psikolog, penyuluh, petani, dan pihak-pihak terkait lainnya. Dengan kata lain, acara televisi pembangunan pedesaan ini menjadi sebuah tontonan dan juga menjadi tuntunan (edutainment) masyarakat pedesaan.

\section{Sistem Penyiaran Televisi Pembangunan Pedesaan}

Telah dijelaskan bahwa siaran pertanian atau pembangunan pedesaan sesungguhnya sudah lama dilakukan baik oleh TVRI sebagai televisi milik pemerintah dan juga setasiun televisi swasta (nasional dan lokal). Namun, jika dibandingkan dengan kompleknya masalah pertanian dan pembangunan pedesaan, acara-acara tersebut masih relatif kecil. Acara televisi baik TVRI apalagi televisi swasta masih didominasi oleh unsur hiburan atau informasi yang kurang relevan dengan pembangunan pedesaan.

Sedikitnya substansi acara yang bermuatan pembangunan pedesaan, juga diperparah dengan waktu penayangan yang tidak tepat bagi petani atau masyarakat di pedesaan. Misalnya, acara-acara tersebut ditayangkan pada siang hari ketika masyarakat desa sedang bekerja di sawah atau ladang. Di sisi lain, banyaknya setasiun televisi baik lokal maupun nasional, selain memberikan alternatif pilihan, ternyata dapat membingungkan masyarakat. Masyarakat kurang mengetahui acara-acara yang sesuai dengan kebutuhan mereka, baik nama acara, jam penayangan, dan setasiun mana yang menayangkan acara tersebut. Oleh karena itu, penyiaran Televisi Pembangunan Pedesaan harus disiarkan melalui channel khusus. Seperti halnya China, siaran televisi pemberdayaan petani dilakukan melalui satu channel khusus setasiun televisi milik pemerintah yaitu Center of China Television pada channel 7 (CCTV 7) (Pustekkom, 2006).

Sesuai dengan Undang-Undang Republik Indonesia Nomor 32 Tahun 2002 tentang Penyiaran, setasiun televisi yang dapat mengundara ke seluruh wilayah Indonesia adalah Televisi Republik Indonesia (TVRI) sebagai Lembaga Penyiaran Publik. Saat ini TVRI menggunakan dua channel yaitu Programa 1 dan Programa 2. Dalam kenyataanya pemanfaatan programa 2 ini masih belum optimal (hanya untuk wilayah DKI Jakarta). Mengingat keterbatasan frekuensi khususnya dengan teknologi analog yang saat ini digunakan teknologi televisi di Indonesia, maka Siaran Pembangunan Pedesaan dapat mengoptimalkan Programa 2 TVRI. Oleh karena itu, dalam mewujudkan Siaran Pembangunan Pedesaan tidak perlu membangun setasiun televisi baru, akan tetapi mengoptimalkan TVRI sebagai setasiun TV Publik. Di sisi lain, perkembangan teknologi pertelevisian yang sedang dirintis melalui teknologi digital, dapat mengatasi keterbatasan frekuensi dan meningkatkan kualitas gambar dan suara siaran televisi (Kemkominfo, 2008). Ini berarti peluang merealisasikan siaran Televisi Pembangunan Pedesaan melalui saluran khusus sangat memungkinkan.

Sistem penyiaran Televisi Pembangunan Pedesaan dilakukan melalui saluran khusus di TVRI yang mengudara secara nasional dan disiarkan selama 24 jam. Supaya siaran Televisi Pembangunan Pedesaan berjalan efektif termasuk mengatasi perbedaan waktu Indonesia Bagian Timur, Tengah dan Barat maka pola siaran menggunakan rumus $8 \times 3$ per hari. Artinya, acara disiarkan 8 jam pada pagi hari misalnya dari pukul 08.00 s.d. 16.00, kemudian acara yang sama diulang pada pukul 16.00 s.d. 24.00 , dan diulang lagi yang ketiga kalinya pada pukul 24.00 s.d. 08.00 (keesokan harinya). Dengan pola ini 
masyarakat yang tidak bisa menonton pagi hari karena sedang bekerja, bisa menonton pada sore hari atau malam hari.

Dengan cara ini petani, penyuluh, dan masyarakat lainnya di berbagai pelosok tanah air dapat mengikuti Siaran Pembangunan Pedesaan sesuai dengan waktu dan kesempatan yang mereka miliki. Siaran Televisi Pembangunan Pedesaan juga akan menjadi siaran alternatif di tengah-tengah gencarnya persaingan acara televisi swasta dan televisi asing. Masyarakat memiliki saluran televisi yang tidak hanya menghibur tetapi memberikan manfaat dalam meningkatkan kualitas kehidupannya.

\section{Pemanfaatan Televisi Pembangunan Pedesaan}

Efektivitas siaran televisi pembangunan pedesaan pada akhirnya bergantung pada sejauhmana siaran tersebut dimanfaatkan oleh masyarakat khususnya masyarakat pedesaan. Oleh karena itu, pengembangan setasiun televisi pembangunan pedesaan perlu dirancang hingga aspek strategi pemanfaatan oleh sasaran yang dituju dalam hal ini masyarakat pedesaan.

Media massa menurut teori agenda-setting dari McCombs dan DL Shaw memiliki pengaruh dan penekanan informasi tertentu terhadap masyarakat. Namun, teori ini diimbangi oleh teori Uses and Gratifications Elihu Katz (Severin dan Tankard, 2001), bahwa pengguna (uses) media atau khalayak adalah aktif dan selektif dalam menggunakan media untuk memenuhi kebutuhan dan kepentingannya. Oleh karena itu, kesadaran masyarakat pedesaan perlu ditumbuhkembangkan untuk menonton acara televisi yang memiliki manfaat bagi kehidupan mereka.

Kesadaran masyarakat desa akan kebutuhan informasi usaha pertanian dan pembangunan pedesaan harus ditumbuhkan. Kebutuhan ini menurut Asngari (2006) adalah bagaimana menumbuhkan kebutuhan nyata (real needs) diubah menjadi kebutuhan yang dirasakan (felt needs). Kebutuhan masyarakat pedesaan tidak hanya hiburan, tetapi yang lebih penting adalah bagaimana meningkatkan kemampuan usaha pertanian dan kualitas kehidupan mereka. Ini adalah real needs yang perlu diubah menjadi felt needs. Dengan adanya kedasaran akan ke- butuhan tersebut maka masyarakat didorong untuk memenuhi kebutuhan itu, salah satunya melalui tontonan yang disajikan televisi pembangunan pedesaan.

Pemanfaatan media massa khususnya televisi sangat terkait dengan kemudahan akses media tersebut (Anwas, 2009). Dalam hal ini perlu mengupayakan siaran Televisi Pembangunan Pedesaan agar bisa diterima oleh seluruh masyarakat pedesaan. Jika Televisi Pembangunan Pedesaan disiarkan melalui TVRI maka daerahdaerah yang tidak menerima siaran (blank spot) TVRI, perlu bekerja sama dengan setasiun lokal, setasiun televisi kabel, termasuk menggunakan teknologi satelit.

Untuk meningkatkan efektivitas pemanfaatan, kegiatan sosialisasi kepada masyarakat juga perlu dilakukan. Kegiatan ini dilakukan secara langsung dan berkesinambungan. Begitu pula tokoh masyarakat dan agama dilibatkan.

Pengembangan setasiun Televisi Pembangunan Pedesaan juga perlu dukungan pihak swasta, melalui program corporate social responsibility. Sebagaimana yang telah diatur dalam Keputusan Menteri BUMN Nomor KEP-236/ MBU/2003 dan Undang-Undang Nomor 40 Tahun 2007, bahwa setiap perusahaan yang mengelola sumber daya alam memiliki kewajiban menyisihkan dari sebagian keuntungannya untuk peningkatan kesejahteraan dan taraf hidup masyarakat di sekitarnya. Bentuk kepedulian terhadap perbaikan lingkungan sosial ini melalui dukungan pengembangan acara dan penyiaran acara di Televisi Pembangunan Pedesaan.

Masyarakat dalam hal ini masyarakat desa perlu dilibatkan baik langsung maupun tidak dalam pengembangan Televisi Pembangunan Pedesaan. Mereka tidak hanya menjadi objek tetapi juga sekaligus sebagai subjek, dilibatkan mulai dari tahap perencanaan, produksi acara, pemanfaatan, pengawasan, hingga evaluasi dan tindak lanjutnya. Dengan cara ini mereka secara emosional memiliki keterlibatan, sehingga mereka akan memiliki kecintaan yang tidak hanya menonton tetapi menerapkan materi yang disajikan dalam siaran televisi dalam kehidupan mereka sehari-hari. Hal ini penting sehingga tujuan penyiaran Televisi Pembangunan Pedesaan bisa tercapai, yaitu meningkatkan 
kualitas kehidupan dan kesejahteraan masyarakat pedesaan.

\section{Simpulan dan Saran Simpulan}

Mewujudkan Televisi Pembangunan Pedesaan adalah sebuah keharusan dalam memenuhi kebutuhan informasi yang terus berkembang bagi masyarakat pedesaan di negeri agraris ini. Hal ini karena media televisi selain telah teruji secara akademik mampu mempengaruhi perilaku masyarakat, juga media massa ini paling digemari dan paling banyak dimiliki masyarakat pedesaan. Pemanfaatan televisi untuk pembangunan pedesaan masih belum optimal. Oleh karena itu, di Indonesia, pengembangan Siaran Televisi Pembangunan Pedesaan perlu segera direalisasikan oleh pemerintah dalam meningkatkan kualitas SDM masyarakat pedesaan guna meningkatkan kehidupan dan kesejahteraannya.

Substansi acara televisi pembangunan pedesaan harus memperhatikan prinsip-prinsip pembangunan masyarakat desa. Pembangunan pedesaan tidak terbatas pada peningkatan usaha pertanian, tetapi banyak aspek kehidupan masyarakat yang perlu ditingkatkan sesuai dengan kebutuhan dan potensi mereka, melalui hasil analisis kebutuhan masyarakat di pedesaan.

Sajian acara Televisi Pembangunan Pedesaan, selain materinya harus bermanfaat bagi masyarakat pedesaan, juga unsur kemenarikan acara sangat penting, sehingga acara ini menjadi sebuah tontonan menarik dan juga memberikan tuntunan bagi masyarakat pedesaan (edutainment).

Mewujudkan Siaran Pembangunan Pedesaan, dapat mengoptimalkan TVRI sebagai setasiun TV Publik, melalui channel khusus, misalnya mengoptimalkan Programa 2. Perintisan perpindahan teknologi pertelevisian dari analog menjadi digital dapat mengatasi keterbatasan frekuensi, sehingga secara teknis peluang merealisasikan siaran Televisi Pembangunan Perdesaan melalui channel khusus sangat dimungkinkan.

Sistem penyiaran Televisi Pembangunan Pedesaan dilakukan melalui saluran khusus di TVRI yang mengudara secara nasional yang disiarkan selama 24 jam, dengan pola siaran 8 jam, kemudian diulang dua kali setiap harinya, memungkinkan masyarakat di berbagai pelosok tanah air dapat mengikuti siaran ini sesuai dengan waktu dan kesempatan yang mereka miliki, baik pagi, sore atau malam hari.

Efektivitas siaran Televisi Pembangunan Pedesaan pada akhirnya bergantung pada sejauh mana siaran tersebut dimanfaatkan oleh masyarakat pedesaan dalam meningkatkan kualitas kehidupannya ke arah yang lebih baik (sejahtera). Oleh karena itu, diperlukan strategi pemanfaatan siaran dengan melibatkan semua unsur terkait, termasuk masyarakat pedesaan.

\section{Saran}

Advokasi terhadap pemerintah (pusat dan daerah) serta pihak lainnya perlu terus dilakukan oleh para akademisi, peneliti, penyuluh, dan masyarakat pedesaan sehingga terwujud adanya komitmen dan kebijakan untuk mewujudkan siaran Televisi Pembangunan Pedesaan dalam membangun SDM petani dan masyarakat pedesaan lainnya guna meningkatkan kualitas kehidupan dan kesejahteraan.

Kesadaran masayarakat desa akan kebutuhan informasi tentang usaha pertanian dan pembangunan pedesaan harus ditumbuhkan dari kebutuhan nyata (real needs) diubah menjadi kebutuhan yang dirasakan (felt needs). Masyarakat perlu dibina untuk bisa memilih informasi dari media massa khususnya televisi yang bermanfaat bagi meningkatkan kualitas kehidupannya.

Dalam pengembangan Televisi Pembangunan Pedesaan, pihak-pihak terkait seperti pemerintah daerah, swasta, dan yang lebih penting adalah masyarakat desa perlu dilibatkan. Mereka tidak hanya menjadi objek tetapi juga sekaligus sebagai subjek, dilibatkan mulai dari tahap perencanaan, produksi acara, pemanfaatan, pengawasan, hingga evaluasi dan tindak lanjutnya. Dengan cara ini mereka memiliki kecintaan yang tidak hanya menonton tetapi menerapkan materi yang disajikan dalam siaran televisi dalam kehidupan sehari-hari. Hal ini penting sehingga tujuan penyiaran Televisi Pembangunan Pedesaan untuk meningkatkan kualitas kehidupan dan kesejahteraan masyarakat pedesaan bisa tercapai. 
Perlu dilakukan kajian dan penelitian lebih mendalam dan operasional tentang pengembangan substansi dan format acara, sistem penyiaran, serta bentuk kerja sama yang bisa saling menguntungkan berbagai pihak terkait dalam pengembangan Siaran Televisi Pembangunan Pedesaan.

\section{Pustaka Acuan}

Anwas, Oos M. 2009. Pemanfaatan Media dalam Pengembangan Kompetensi Penyuluh Pertanian. Disertasi: Program Studi Ilmu Penyuluhan Pembangunan, Departemen Sains Komunikasi dan Pengembangan Masyarakat Pascasarjana IPB Bogor.

Asngari, Pang S. 2006. "Kumpulan Bahan Kuliah Prinsip-prinsip Penyuluhan". Program Studi Ilmu Penyuluhan Pembangunan. Sekolah Pascasarjana. Bogor: IPB. (Tidak dipublikasikan)

Badan Pusat Statistik (BPS) Republik Indonesia. 2010. Indikator Sosial Budaya; Persentase Penduduk Berumur 10 Tahun ke Atas yang Menonton Televisi, Mendengarkan Radio, dan Membaca Surat Kabar/ Majalah. http://www.bps.go.id/tab_sub/view.php?tabel=1\&daftar=1\&id_subyek=27\& notab=35 (18 September 2010).

Hafsah, Mohammad Jafar. 2009. "Penguatan Peran PAPPI dalam Mendukung Tumbuh dan Berkembangnya Modal Sosial di Masyarakat" Makalah Simposium dan Kongres Perhimpunan Ahli Penyuluhan Pembangunan Indonesia (PAPPI). Bogor, 24 s.d. 25 November 2009.

Kementerian Komunikasi dan Informatika. 2008. Kebijakan Siaran Digital di Indonesia. Jakarta: Kemkominfo.

Keputusan Menteri Negara BUMN Nomor KEP-236/MBU/2003 tentang Perseroan Terbatas.

Littlejohn, SW. 1996. Theories of Human Communication. Wadsworth, Publishing Company. An International Thomson Publishing Company.

McQuel, Denis and Sven Windahl. 1996. Communication Model for the Study of Mass Communications. Second edition. New York: Longman.

McQuail, Denis. 1995. Mass Communication Theory. Third Edition. London: Sage Publication.

Nasution, Zulkarimein. 2007. Komunikasi Pembangunan: Pengenalan Teori dan Penerapannya. Jakarta: Rajawali Press.

Oepen, Manfred. 1988. Development Support Communication in Indonesia. Edisi Indonesia: Media Rakyat: Komunikasi Pembangunan Masyarakat. P3M Jakarta.

Pustekkom, Kemdiknas. 2006. Laporan Studi Banding Pemanfaatan Media Televisi untuk Pendidikan. Jakarta: Pustekkom Kemdiknas.

Sanders, Irwin T. 1958. The Community An Introduction to a Social System. New York: The Ronald Press Company.

Severin, J. Werner dan James W. Tankard. 2001. Communication Theory: Origin, Methods, and Uses in The Mass Media. Eddison Wesley Lngman, Inc.

Straubhaar, Joseph dan Rober LaRose. 2002. Media Now: Communications Media in the Informatyion Age. Third Edition. Belmon. CA: Wadsworth.

Slamet, Margono. 2003. "Meningkatkan Partisipasi Masyarakat dalam Pembangunan Perdesaan." Dalam Membentuk Pola Perilaku Manusia Pembangunan. Diedit oleh: Adjat Sudrajat dan Ida Yustina. Bogor: IPB Press.

Sumaryo dan Agus Safari. 2007. Pembangunan Masyarakat: Teori dan Implikasinya di Era Otonomi Daerah. Bogor: CDI Press.

Suryantini, Heryanti. 2003. Kebutuhan Informasi dan Motivasi Kognetif Penyuluh Pertanian serta Hubungannya dengan Penggunaan Sumber Informasi. Bogor: Jurnal Perpustakaan Pertanian Vo. 12 No. 2.

Undang-Undang Republik Indoesia Nomor 40 Tahun 2007 tentang Perseroan Terbatas Undang-Undang Republik Indonesia Nomor 32 Tahun 2002 tentang Penyiaran Wilkinson, Gene L. 1980, Media dalam Pembelajaran; Penelitian Selama 60 Tahun, Edisi Indonesia, Jakarta: CV Rajawali. 